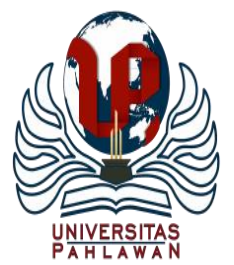

Edukatif : Jurnal Ilmu Pendidikan Volume 3 Nomor 4 Tahun 2021 Halm 2245 - 2255

EDUKATIF: JURNAL ILMU PENDIDIKAN

Research \& Learning in Education

https://edukatif.org/index.php/edukatif/index

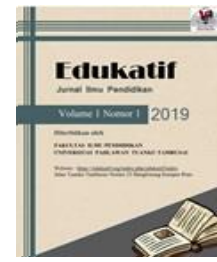

\title{
Pengembangan Permainan Berburu Harta Karun Berbasis Karya Seni Lukis untuk Memfasilitasi Perkembangan Sosial Emosional Anak Usia Dini
}

\author{
Hafshania Nafisah $^{1 凶}$, Edi Hendri Mulyana ${ }^{2}$ Rosarina Giyartini $^{3}$ \\ Universitas Pendidikan Indonesia, Indonesia ${ }^{1,2,3}$ \\ E-mail : hafshanianafisah98@gmail.com ${ }^{1}, \underline{\text { edihm@ @upi.edu }}^{2}, \underline{\text { rosarina@ }}$ upi.edu $^{3}$
}

\begin{abstract}
Abstrak
Tujuan dari penelitian ini adalah untuk mengembangkan permainan berburu harta karun berbasis membuat karya seni lukis untuk memfasilitasi perkembangan sosial emosional anak usia dini. Jenis metode ini adalah EDR (Education Desain Research). Penelitian ini berbasis desain dan rancangan produk dengan menggunakan pendekatan mix method research bahwa dengan kombinasi pendekatan kualitatif dan kuantitatif. Pengumpulan data dilakukan menggunakan instrumen berupa wawancara, observasi, dan kuesioner. Subjek dalam penelitian ini adalah 6 orang anak usia 5-6 tahun yang bersekolah di TK Ibadurrahman, Kecamatan Tawang, Kota Tasikmalaya, Jawa Barat. Hasil rata-rata penilaian ahli kurikulum dan pembelajaran AUD, ahli permainan, ahli materi pengembangan seni AUD, dan ahli perkembangan sosial emosional AUD, hasil validasi produk adalah 91,5 \% dengan kategori sangat layak. Hasil uji coba pada peserta didik kelompok B TK Ibadurrahman rata-rata sebesar 95,83\% dengan kategori anak Berkembang Sangat Baik (BSB). Hasil penelitian tersebut dapat disimpulkan bahwa pengembangan permainan berburu harta karun berbasis karya seni lukis untuk memfasilitasi perkembangan sosial emosional anak usia dini sangat layak digunakan dalam pembelajaran.
\end{abstract}

Kata Kunci: Permainan Berburu Harta Karun, Seni Lukis, Perkembangan Sosial Emosional, Anak Usia Dini

\begin{abstract}
The purpose of this research is to develop a treasure hunting game based on making artworks to facilitate the social-emotional development of early childhood. This type of method is EDR (Education Design Research). This research is based on product design and design using a mixed method research approach that combines qualitative and quantitative approaches. Data was collected using instruments in the form of interviews, observations, and questionnaires. The subjects in this study were 6 children aged 5-6 years who attended Ibadurrahman Kindergarten, Tawang District, Tasikmalaya City, West Java. The average results of the assessments of AUD curriculum and learning experts, game experts, AUD arts development materials experts, and AUD socio-emotional development experts, the result of product validation is $91.5 \%$ with a very feasible category. The results of the trial on group B students of Ibadurrahman Kindergarten were an average of $95.83 \%$ in the category of very well-developed children (BSB). The results of this study can be concluded that the development of painting-based treasure hunting games to facilitate the socio-emotional development of early childhood is very suitable for use in learning.
\end{abstract}

Keywords: Treasure Hunt Game, Art Paint, Emotional-Social Development, Early Childhood

Copyright (c) 2021 Hafshania Nafisah, Edi Hendri Mulyana, Rosarina Giyartini

$\triangle$ Corresponding author:

Email : hafshanianafisah98@gmail.com

DOI : https://doi.org/10.31004/edukatif.v3i4.1165

ISSN 2656-8063 (Media Cetak)

ISSN 2656-8071 (Media Online)

Edukatif : Jurnal Ilmu Pendidikan Vol 3 No 4 Tahun 2021 p-ISSN 2656-8063 e-ISSN 2656-8071 
2246 Pengembangan Permainan Berburu Harta Karun Berbasis Karya Seni Lukis untuk Memfasilitasi Perkembangan Sosial Emosional Anak Usia Dini - Hafshania Nafisah, Edi Hendri Mulyana, Rosarina Giyartini

DOI: https://doi.org/10.31004/edukatif.v3i4.1165

\section{PENDAHULUAN}

Pendidikan dimulai sejak anak usia dini, yaitu masa keemasan atau kerap disebut dengan Golden Age. Pada masa ini anak akan mengalami pertumbuhan dan perkembangan yang pesat. Hal ini berlangsung pada saat anak dalam kandungan hingga anak usia enam tahun. Oleh sebab itu perkembangan pada masa ini akan menjadi penentu bagi perkembangan selanjutnya sehingga berkembangang sesuai dengan semestinya. Maka selaras dengan tujuan Pendidikan Anak Usia Dini (PAUD) menurut Undang-Undang Undang-Undang nomor 20 tahun 2003 tentang sistem pendidikan nasional, bahwa pendidikan anak usia dini adalah suatu upaya pembinaan yang ditunjukkan kepada anak sejak lahir sampai dengan usia enam tahun yang dilakukan dengan memberikan rangsangan pendidikan membantu pertumbuhan dan perkembangannya baik secara jasmani dan rohani agar anak siap dalam memasuki pendidikan selanjutnya. (Fauziddin \& Mufarizuddin, 2018)

Pendidikan yang diberikan kepada anak berbeda dengan cara menyampaikan pembelajaran pada orang dewasa, karena anak belajar seraya bermain, ataupun bermain seraya belajar. Wiwik Pratiwi (2017) juga menegaskan bahwa pembelajaran yang harus disampaikan pada anak usia dini itu pembelajaran yang menyenangkan bagi anak. Kegiatan bermain tentunya sangat diminati oleh setiap anak, secara tidak langsung atau kita sadari dengan bermain dapat mempengaruhi perkembangan anak. Pengaruh bermain bagi anak dapat mempengaruhi aspek perkembangan pada diri anak. Aspek-aspek perkembangan pada anak usia dini telah ditentukan indikatornya dalam Standar Tingkat Pencapaian Perkembangan Anak (STPPA) yang tercantum dalam Permendikbud 137 tahun 2014 sesuai dengan tingkat usia. STPPA adalah kriteria tentang kemampuan yang dicapai anak pada seluruh aspek perkembangan dan pertumbuhan, yang mencakup aspek nilai agama dan moral, fisik motorik, kognitif, bahasa, sosial-emosional dan seni. (MENTERI PENDIDIKAN DAN KEBUDAYAAN REPUBLIK INDONESIA, 2014)

Pembelajaran melalui permainan membuat anak akan senang dan beberapa keunggulan belajar seraya bermain adalah menyenangkan, menghibur anak dan permainan mengajar anak aktif belajar sehingga tidak merasa bosan akan tetapi pembelajaran lebih terasa menyenangkan. (Aprilia, 2021) Beberapa pengaruh bermain bagi perkembangan anak diantaranya dapat mempengaruhi menambahnya wawasan pada diri anak, penyaluran energi positif seperti dapat menyalurkan emosional yang terpendam, dorongan komunikasi, rangsangan untuk kreatif, dan anak dapat belajar bermasyarakat dengan teman ataupun lingkungan sekitarnya. (Wiwik Pratiwi, 2017)

Mengembangkan kemampuan sosial pada diri anak tanpak pada caranya bergaul dengan teman sebayanya. Sering kali kita menganggap tindakan sosial merujuk pada bagaimana anak berperilaku sopan atau tidaknya anak pada usia di atas mereka, tetapi dalam kejiwaan anak usia dini, tindakan sosial seperti halnya bergaul bagi kelompok usianya jarang melibatkan tata karma dan biasanya masih bersikap egois. Fokus anak hanya pada diri sendiri, akan tetapi pandangan egois ini tidak berlaku jika kita ingin mengenal dunia lebih luas seperti menginginkan pertemanan dengan orang lain. Tujuan dari banyaknya prasekolah atau lembaga sekolah lainnya ingin membantu agar anak berkembang dalam kemampuan sosial dasarnya. Dalam jurnal penelitian Gusmaniarti (2018) ada pengaruh pembelajaran sentra seni dan kreasi terhadap perkembangan sosial emosional anak usia dini, karena khususnya saat anak bermain seni anak dapat berkreasi dan berimajinasi dengan teman-temannya seperti dalam berkomunikasi dan bersosialisasi dapat menciptakan pembelajaran yang menyenangkan bagi anak. Salah satu contoh sentra seni yaitu seni lukis. Melukis bagi anak merupakan media kegiatan yang dapat mengembangkan potensi diri dan dengan melukis anak akan menciptakan sebuah hasil karya seni lukis. Ketika telah menyelesaikan karya maka anak dapat memperlihatkan hasil lukisannya, anak yang mampu memperlihatkan hasil karyanya dapat disebut percaya diri.

Manfaat dari bermain bagi anak yaitu 1) membantu pertumbuhan dan perkembangan anak, 2) mempunyai unsur berpetualang, 3) mempunyai pengaruh dalam membentuk hubungan antar pribadi. (Wiwik 
2247 Pengembangan Permainan Berburu Harta Karun Berbasis Karya Seni Lukis untuk Memfasilitasi Perkembangan Sosial Emosional Anak Usia Dini - Hafshania Nafisah, Edi Hendri Mulyana, Rosarina Giyartini

DOI: https://doi.org/10.31004/edukatif.v3i4.1165

Pratiwi, 2017) Sedangkan fungsi bermain bagi anak yaitu: 1) memanfaatkan energi berlebih pada anak, 2) memulihkan tenaga dan perasaan jenuh, 3) melatih keterampilan tertentu 4) memberikan kesempatan proses sosial anak (Ardini \& Lestariningrum, 2018).

Seni rupa menurut Pamadhi (2018) seni rupa adalah karya rupa yang menghasilkan pemikiran dan perasaan pada anak tentang diri dan lingkungan sekitarnya. Sedangkan pendidikan seni rupa untuk anak adalah upaya yang dapat mengembangkan diri untuk mengenali pribadi sendiri, menggali dan mengembangkan kreativitas pada anak dalam bidang seni rupa. (Yuninigsih, 2019) Seni rupa memiliki beberapa cabang seni salah satunya seni lukis yang dimana bahasa visual yang diungkapkan dalam goresan dan gambaran sebagai salah satu cara mereka berkomunikasi, dan seni lukis dapat membuat karya ekspresi yang menjelaskan makna dari pelaku seni lukis. Kesegaran muncul dari pilihan warna dalam lukisan anak yang terkadang mengejutkan orang dewasa, karena anak akan langsung saja mencampurkan warna tanpa memikirkan bagus atau tidak. Seperti warna pohon identik warna hijau atau kuning seperti musim semi, akan tetapi anak menggunakan gradasi warna hijau kuning dan menambahkan gambar buah apel di pohon tersebut. (Wiratno, 2018)

Anak yang berusia 5-6 tahun masuk pada tahap Cooperative play, yang meliputi interaksi sosial dalam kelompok yang memiliki aktivitas bermain yang cukup aktif. Tahap ini anak melakukan aktivitas bermain secara berkelompok, banyak permainan aktif yang dapat mengembangkan sosial emosional anak, salah satunya permainan berburu harta karun. (Veronika \& Puspitasari, 2018)

Permainan berburu harta karun berbasis karya seni lukis untuk memfasilitasi perkembangan sosial emosional anak usia dini. Permainan ini dapat dimainkan berdasarkan untuk membuat karya seni lukis. Jadi sebelum anak melukis dapat melakukan permainan berburu harta karun dulu. Permainan dapat dilaksanakan di dalam ruangan ataupun di luar ruangan dengan cara berkelompok sehingga dapat mengembangkan sosial emosional anak usia dini. (Safitri et al., 2020)

Dari pengamatan dan hasil wawancara pada 2 orang guru di TK Ibadurrahman Kecamatan Tawang, Kota Tasikmalaya, masalah yang peneliti temukan adalah 1) ketika peneliti uji coba pertama melukis tanpa adanya permainan, anak lebih banyak diam dan interaksi dengan temannya tidak terlalu terjalin karena anak fokus pada lukisannya. 2) permainan belum pernah dilakukan disekolah tersebut sehingga saat dikenalkan anak antusias untuk mencoba permainan berburu harta karun berbasis karya seni lukis. 3) fasilitas alat dan bahan untuk membuat karya seni lukis belum lengkap. 4) anak masih ada yang belum bias mengontrol emosi saat bermain dengan teman sebayanya dan belum percaya diri dalam memperlihatkan hasil karyanya.

Maka dengan kesenjangan yang terjadi di lapangan pembelajaran yaitu permainan berburu harta karun berbasis karya seni lukis sehingga dapat terfasilitasi perkembangan sosial emosinal. Permainan berburu harta karun berbasis karya seni lukis dipilih dikarenakan permainan ini bermain dengan cara berkelompok sehingga anak bekerjasama untuk menemukan benda-benda yang disembunyikan, anak akan saling berkomunikasi, melatih saling membagi informasi dan mencocokkan benda yang disembunyikan dengan peta yang menjadi alat bantu permainan. Permainan ini memberi pengalaman baru bagi anak, dan dengan kontribusi ini anak ketika hendak membuat karya seni lukis dapat melakukan permainan berburu harta karun. Permainan ini juga menjadi wadah untuk memfasilitasi perkembangan sosial emosioanl anak seperti memberikan nama pada hasil karya lukis, menceritakan, dan menjadi tempat anak saling berkomunikasi baik untuk anak yang pendiam, aktif dan lainnya.

Penelitian terdahulu dilakukan oleh (Wina et al., 2019) penelitian ini bertujuan menghasilkan produk permainan harta karun si bola-bola dalam pembelajaran sosial emosional di Taman Kanak-Kanak. Kesimpulan permainan ini, layak digunakan dalam pembelajaran dan dapat meningkatkan sosial emosional anak. Maka berdasarkan penelitian terdahulu, keyakinan untuk mengembangkan permainan berburu harta karun berbasis karya seni lukis untuk memfasilitasi perkembangan sosial emosional anak usia dini. Pada 
2248 Pengembangan Permainan Berburu Harta Karun Berbasis Karya Seni Lukis untuk Memfasilitasi Perkembangan Sosial Emosional Anak Usia Dini - Hafshania Nafisah, Edi Hendri Mulyana, Rosarina Giyartini

DOI: https://doi.org/10.31004/edukatif.v3i4.1165

penelitian pengembangan ini, dikembangkan pada anak berusia 5-6 tahun di kelompok B dengan tema binatang, sub tema burung, dan sub-sub tema burung hantu. Rancangan permainan ini yaitu berburu bendabenda yang disembunyikan, benda tersebut merupakan alat dan bahan untuk membuat karya seni lukis seperti easel, koas, cat warna dll. Anak mencari dengan alat permainannya yaitu peta harta karun. Anak berburu sampai menemukan harta karun (box berisikan kanvas, koran dll). Kelebihan dari permainan yang dikembangkan ini untuk belajar anak yaitu dikemas dengan alat sederhana seperti peta agar memudahkan anak untuk mencari harta karun, dan alat tersebut dapat digulung, tahan lama, mudah dibawa dan praktis dalam penggunaannya. Penelitian ini merupakan pembaharuan dari penelitian sebelumnya yang dimana produk permainan dapat mengembangkan sosial emosional melalui permainan si bola-bola, sedangkan peneliti menyajikan permainan berburu harta karun dengan berdasarkan karya seni lukis. Hal ini didasari di lapangan ketika membuat karya seni lukis, pendidik akan langsung memberikan media, alat dan bahan melukis tanpa menjelaskan terlebih dahulu apa itu melukis, alat dan bahan penunjang lainnya. Maka dengan itu peneliti mengembangkan permainan sebelum membuat karya seni lukis sehingga anak tertantang dan dalam perkembangan sosial emosional anak lebih terstimulus dengan baik. Dan ada kesenjangan pada teori dari Gusmaniarti (2018) ada pengaruh pembelajaran sentra seni dan kreasi terhadap perkembangan sosial emosional anak usia dini, karena khususnya saat anak bermain seni anak dapat berkreasi dan berimajinasi dengan teman-temannya seperti dalam berkomunikasi dan bersosialisasi dapat menciptakan pembelajaran yang menyenangkan bagi anak. Sedangkan yang terjadi dilapangan saat anak melukis, ada beberapa anak lebih fokus pada karyanya sendiri sehingga komunikasi dan sosial anak kurang terjalin.

\section{METODE PENELITIAN}

Metode penelitian ini adalah Educational Design Research (EDR) dengan pendekatan penelitian campuran (mix method). Metode EDR menurut Barab dan Squire dalam (Lidinillah, 2012) mengemukakan EDR adalah "rangkaian pendekatan, dengan maksud menghasilkan toeri-teori baru, artefak, dan model praktis dalam menjelaskan dan bertujuan pada pembelajaran dengan pengaturan yang alami”. Lagkah-langkah yang dikembangkan dari model pengembangan karya McKenney \& Reeves yaitu dengan tiga tahap penelitian, yaitu tahap analysis and ecploration, design and contruction, dan evaluation and reflection. Penelitian dilakukan di TK Ibadurrahman, Kecamatan Tawang Kota Tasikmalaya, dengan subjek penelitian yaitu anak berusia 5-6 tahun dengan jumlah 4 anak. Pengumpulan data menggunakan teknik wawancara, observasi, dan kuesioner. Pengumpulan data digunakan melalui media handphone (WA), tatap muka dan pengiriman jasa kirim. Teknik analisis menggunakan model Miles dan Huberman (Sugiyono, 2019). Yaitu langkah-langkah yang dilakukan dalam analisis data penelitian ini yaitu data reduction (mengorganisir data), data display (membuat uraian teperinci), dan conclusion drawing/verification (melakukan interprestasi dan kesimpulan). Analisis pertama menggunakan deskriptif kualitatif yaitu dengan hasil pendahuluan wawancara pada 2 guru. Analisis kedua untuk mengetahui hasil rancangan produk hasil dari penilaian ahli menggunakan statistik deskriptif yang hasil penghitungannya mengambil rata-rata dari validator. Ketiga uji kelayakan diperoleh dari guru, serta hasil perkembangan sosial emosional anak dalam menggunakan produk yang dikembangkan oleh peneliti, hasil analisis ini menggunakan statistika desktiptif. Kriteria penilaian kuesioner ialah sebagai berikut:

Tabel 1

Kriteria Penilaian Angket

\begin{tabular}{cc}
\hline Jawaban & Score \\
\hline Sangat Baik (SB) & 4 \\
\hline Baik (B) & 3 \\
\hline Cukup Baik (C) & 2 \\
\hline Kurang Baik (K) & 1 \\
\hline
\end{tabular}

Edukatif : Jurnal Ilmu Pendidikan Vol 3 No 4 Tahun 2021 p-ISSN 2656-8063 e-ISSN 2656-8071 
2249 Pengembangan Permainan Berburu Harta Karun Berbasis Karya Seni Lukis untuk Memfasilitasi Perkembangan Sosial Emosional Anak Usia Dini - Hafshania Nafisah, Edi Hendri Mulyana, Rosarina Giyartini

DOI: https://doi.org/10.31004/edukatif.v3i4.1165

(Wijaya Kuswanto \& Dinda Pratiwi, 2020)

Presentase score diperoleh dari masing-masing ahli dan guru kelompok B kemudian di rata-ratakan kembali untuk mendapatkan nilai yang mewakili responden. Presentase untuk kelayakan permainan yang dikembangkan oleh peneliti: Kriteria Tingkat Validitas

Tabel 2

Kriteria Tingkat Validitas

\begin{tabular}{cc}
\hline Jawaban & Score \\
\hline $\begin{array}{c}\text { Sangat Tidak } \\
\text { Layak }\end{array}$ & $<21 \%$ \\
\hline Tidak Layak & $21-40 \%$ \\
\hline Cukup Layak & $41-60 \%$ \\
\hline Layak & $61-80 \%$ \\
\hline Sangat Layak & $81-100 \%$ \\
\hline & (Ernawati, 2017)
\end{tabular}

Selanjutnya proses pembelajaran untuk memenuhi kompetensi perkembangan sosial emosional, salah satunya geran pembelajaran di Amerika Serikat Collaborative for Academic Social and Emotional Learning (CASEL). CASEL sebuah proses dimana anak-anak dan orang dewasa memahami dan dapat mengelola emosi, dengan menetapkan dan mencapai tujuan yang positif, seperti menunjukkan empati pada orang lain, membangun hubungan dengan orang lain dan bertanggung jawab. (CASEL, 2015)

CASEL mengindentifikasi lima perangkat utama dalam pembelajaran sosial emosional, yaitu sebagai berikut:

1. Kesadaran diri (self-awareness)

2. Manajemen diri (self-management)

3. Kesadaran sosial (social-awareness)

4. Keterampilan membangun hubungan (relationship skill)

5. Pengambilan keputusan yang bertanggungjawab (responsible decition-making) (Helaluddin \& Alamsyah, 2019)

Berikut kisi-kisi instrumen untuk mengetahui perkembangan sosial emosional anak:

Tabel 3

Kisi-kisi Perkembangan Sosial Emesional Anak Usia Dini

\begin{tabular}{|c|c|}
\hline Indikator & Deskriptor \\
\hline \multirow{3}{*}{ Memfasilitasi percaya diri } & $\begin{array}{l}\text { Mengelola emosi dengan baik (mampu bersabar ketika menunggu } \\
\text { giliran) }\end{array}$ \\
\hline & Mengenal dan mengungkapkan perasaan dirinya \\
\hline & Percaya diri akan menunjukkan hasil karya seni lukis \\
\hline \multirow{3}{*}{$\begin{array}{l}\text { Memfasilitasi manajemen } \\
\text { diri }\end{array}$} & $\begin{array}{l}\text { Mampu mengendalikan diri dan tidak bersifat impulsive (suatu } \\
\text { tindakan tanpa memikirkan akibat) }\end{array}$ \\
\hline & $\begin{array}{l}\text { Dapat mengendalikan perilaku agresif yang merusak diri sendiri dan } \\
\text { orang lain }\end{array}$ \\
\hline & Mampu memotivasi diri dan orang lain saat bermain \\
\hline \multirow{3}{*}{$\begin{array}{l}\text { Memfasilitasi kesadaran } \\
\text { sosial }\end{array}$} & Empati terhadap teman sebayanya \\
\hline & Menghargai perbedaan perbedaan pendapat orang lain \\
\hline & Menghormati orang lain (memiliki kepekaan terhadap orang lain) \\
\hline \multirow{2}{*}{$\begin{array}{l}\text { Memfasilitasi kemampuan } \\
\text { membangun hubungan }\end{array}$} & Berkomunikasi dengan teman sebayanya \\
\hline & Membangun hubungan dengan berbagi, dan membantu temannya \\
\hline
\end{tabular}


2250 Pengembangan Permainan Berburu Harta Karun Berbasis Karya Seni Lukis untuk Memfasilitasi Perkembangan Sosial Emosional Anak Usia Dini - Hafshania Nafisah, Edi Hendri Mulyana, Rosarina Giyartini

DOI: https://doi.org/10.31004/edukatif.v3i4.1165

\begin{tabular}{ll}
\hline \multicolumn{1}{c}{ Indikator } & \multicolumn{2}{c}{ Deskriptor } \\
\hline \multirow{3}{*}{$\begin{array}{l}\text { Memfasilitasi pengambilan } \\
\text { keputusan } \\
\text { bertanggungjawab }\end{array}$} & $\begin{array}{l}\text { Menyelesaikan masalah (dapat menyelesaikan konflik atau } \\
\text { hambatan yang terjadi saat bermain) }\end{array}$ \\
\cline { 2 - 3 } & $\begin{array}{l}\text { Mengetahui situasi (memerhatikan kepentingan sosial dan senang } \\
\text { menolong orang lain) }\end{array}$ \\
\cline { 2 - 3 } & Bertanggungjawab atas alat dan bahan, dan kebersihan lingkungan \\
\hline
\end{tabular}

\section{HASIL DAN PEMBAHASAN PENELITIAN}

\section{Dasar Kebutuhan Penelitian}

Berdasarkan hasil pengumpulan informasi pada tahap ini yaitu dengan wawancara kepada 2 orang guru kelompok B di TK Ibadurrahman, membuktikan bahwa permainan berburu harta karun berbasis karya seni lukis sebagai proses pembelajaran sesuai dengan kebutuhan di TK Ibadurrahman. Hal ini karena saat pembelajaran terutama di bidang seni lukis anak akan langsung saja melukis di bidang yang sudah disediakan oleh guru. Selain itu terdapat kesenjangan teori menjelaskan kegiatan seni lukis dapat menyenangkan bagi anak, saling berkomunikasi dan dapat menunjukkan karya seni lukisnya akan tetapi di lapangan anak yang pendiam akan terus fokus dan tidak memperhatikan sekitar mereka, ketika menunjukkan hasil karyanya anak juga belum percaya diri.

Dengan demikian, untuk menciptakan pembelajaran yang menyenangkan dan dapat terfasilitasi perkembangan sosial emosional anak, diperlukan suatu hal yang baru agar anak berperan aktif. Maka dengan permainan berburu harta karun berbasis karya seni lukis menjadi solusi untuk memfasilitasi perkembangan sosial emosional anak usia dini.

\section{Rancangan Pengembangan}

Permainan berburu harta karun berbasis karya seni lukis disusun berdasarkan kebutuhan untuk mendukung pembelajaran di kelompok B dengan tema binatang, sub tema burung, sub-sub tema burung hantu, dengan konsep yang dikenalkan dengan desain peta harta karun atau storyboard yang telah dirancang. Setelah itu membuat instrument validasi produk para ahli dan guru, serta diuji coba kepada anak. Berikut tahap pembentukan prototyping permainan berburu harta karun berbasis karya seni lukis berdasarkan data komponen permainan diantaranya terdiri dari, bahan kertas peta harta karun dengan menggunakan luster berukuran A4, gambar pada peta harta karun merupakan benda-benda perlengkapan melukis yang disebumnyikan, teks judul peta harta karun menggunakan font Calibri (body) dan size sedangkan isi tulisan font Times New Roman dan size 28, garis putus-putus menandakan jalan yang harus dilewati untuk menemukan benda yang disembunyikan. Berikut gambar storyboard keseluruhan dari alat permainan berburu harta karun yaitu peta harta karun: 
2251 Pengembangan Permainan Berburu Harta Karun Berbasis Karya Seni Lukis untuk Memfasilitasi Perkembangan Sosial Emosional Anak Usia Dini - Hafshania Nafisah, Edi Hendri Mulyana, Rosarina Giyartini

DOI: https://doi.org/10.31004/edukatif.v3i4.1165

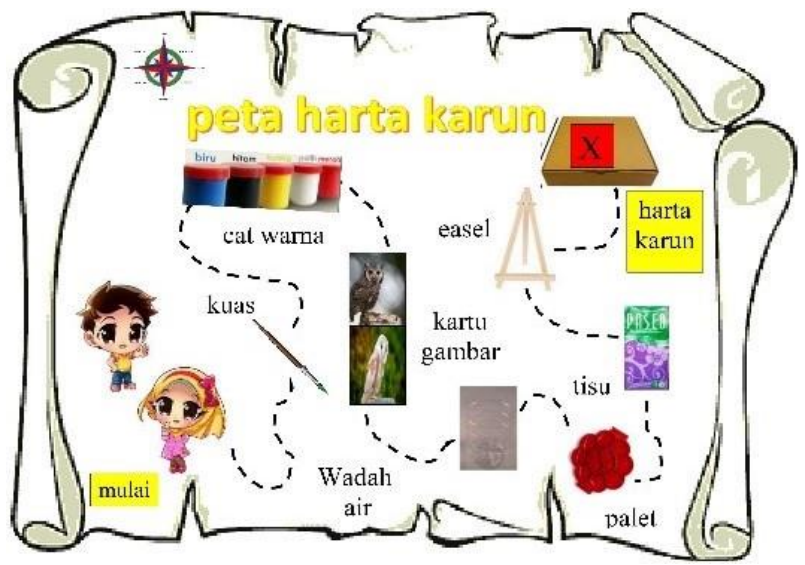

Gambar 1. Peta Harta Karun

Selanjutnya uji validasi produk, peneliti menggunakan skala likert. Berikut uji validasi oleh ahli kurikulum dan pembelajaran PAUD yang dilakukan 2x dengan hasil validasi pertama $78 \%$ dan kedua $89 \%$. Terdapat kenaikan nilai sebesar $11 \%$. Hasil validasi oleh ahli kurikulum dan pembelajaran PAUD:

Tabel 4

Hasil validasi ke-2 oleh ahli kurikulum dan pembelajaran PAUD

\begin{tabular}{cccc}
\hline No & $\begin{array}{c}\text { Aspek Indikator } \\
\text { Penilaian }\end{array}$ & Persantase & Kategori \\
\hline 1 & $\begin{array}{c}\text { Cakupan materi } \\
\text { sesuai dengan } \\
\text { ketentuan } \\
\text { Kurikulum 2013 } \\
\text { Pendidikan Anak } \\
\text { Usia Dini }\end{array}$ & $93 \%$ & Sangat Layak \\
\hline 2 & $\begin{array}{c}\text { Kejelasan materi } \\
\text { yang diberikan }\end{array}$ & $85 \%$ & Sangat Layak \\
\hline Mean & & $89 \%$ & Sangat Layak \\
\hline
\end{tabular}

Berikut uji validasi oleh ahli permainan yang dilakukan 2x dengan hasil validasi pertama $66 \%$ dan kedua $93 \%$. Terdapat kenaikan nilai sebesar Hasil validasi oleh ahli permainan :

Tabel 5

Hasil validasi ke-2 oleh ahli permainan

\begin{tabular}{cccc}
\hline No & $\begin{array}{c}\text { Aspek Indikator } \\
\text { Penilaian }\end{array}$ & Persantase & Kategori \\
\hline 1 & $\begin{array}{c}\text { Kesesuaian } \\
\text { permainan dengan } \\
\text { Kompetensi Dasar } \\
(\text { KD) }\end{array}$ & $100 \%$ & Sangat Layak \\
\hline 2 & $\begin{array}{c}\text { Memenuhi syarat } \\
\text { bermain }\end{array}$ & $87 \%$ & Sangat Layak \\
\hline 3 & $\begin{array}{c}\text { Kelayakan } \\
\text { permainan }\end{array}$ & $93 \%$ & Sangat Layak \\
\hline & Mean & $93 \%$ & Sangat Layak \\
\hline
\end{tabular}

Berikut uji validasi oleh ahli materi pengembangan seni AUD yang dilakukan 2x dengan hasil validasi pertama $75 \%$ dan kedua $93 \%$. Terdapat kenaikan nilai sebesar $18 \%$ Hasil validasi oleh ahli materi seni AUD: 
2252 Pengembangan Permainan Berburu Harta Karun Berbasis Karya Seni Lukis untuk Memfasilitasi Perkembangan Sosial Emosional Anak Usia Dini - Hafshania Nafisah, Edi Hendri Mulyana, Rosarina Giyartini

DOI: https://doi.org/10.31004/edukatif.v3i4.1165

Tabel 6

Hasil validasi ke-2 oleh ahli materi pengembangan seni AUD

\begin{tabular}{cccc}
\hline No & $\begin{array}{c}\text { Aspek Indikator } \\
\text { Penilaian }\end{array}$ & Persantase & Kategori \\
\hline 1 & $\begin{array}{c}\text { Proses berkarya } \\
\text { seni lukis membuat } \\
\text { karya seni lukis }\end{array}$ & $93 \%$ & Sangat Layak \\
\hline Mean & & Sangat Layak \\
\hline
\end{tabular}

Berikut uji validasi oleh ahli perkembangan sosial emosional AUD yang dilakukan $2 \mathrm{x}$ dengan hasil validasi pertama $73 \%$ dan kedua $91 \%$. Terdapat kenaikan nilai sebesar $18 \%$. Hasil validasi oleh ahli materi sosial emosional AUD:

Tabel 7

Hasil validasi ke-2 oleh ahli perkembangan sosial emosional AUD

\begin{tabular}{cccc}
\hline No & $\begin{array}{c}\text { Aspek Indikator } \\
\text { Penilaian }\end{array}$ & Persantase & Kategori \\
\hline 1 & $\begin{array}{c}\text { Memfasilitasi } \\
\text { percaya diri }\end{array}$ & $83 \%$ & Sangat Layak \\
\hline 2 & $\begin{array}{c}\text { Memfasilitasi } \\
\text { manajemen diri }\end{array}$ & $91 \%$ & Sangat Layak \\
\hline 3 & $\begin{array}{c}\text { Memfasilitasi } \\
\text { kesadaran sosial }\end{array}$ & $91 \%$ & Sangat Layak \\
\hline 4 & $\begin{array}{c}\text { Memfasilitasi } \\
\text { kemampuan } \\
\text { membangun } \\
\text { hubungan }\end{array}$ & $100 \%$ & Sangat Layak \\
\hline 5 & $\begin{array}{c}\text { Memfasilitasi } \\
\text { pengambilan } \\
\text { keputusan } \\
\text { bertanggungjawab }\end{array}$ & $91 \%$ & Sangat Layak \\
\hline Mean & $91 \%$ & Sangat Layak \\
\hline
\end{tabular}

Berdasarkan hasil uji validitas produk rata-rata yang diperoleh 91,5\% dengan kategori sangat layak.

\section{Kelayalakan Pengembangan}

Uji produk terhadap dua orang guru dan siswa terlihat bahwa Permainan Berburu Harta Karun Berbasis Karya Seni Lukis Sangat Layak digunakan untuk memfasilitasi perkembangan sosial emosional anak usia dini. Dengan hasil uji kepraktisan bagi guru berenisial SN:

Tabel 8

Hasil uji kepraktisan bagi guru SN

\begin{tabular}{ccc}
\hline No & Indikator & Persantase \\
\hline 1 & $\begin{array}{c}\text { Aspek permainan pada } \\
\text { permbelajaran }\end{array}$ & $93 \%$ \\
\hline 2 & Aspek kelayakan permainan & $100 \%$ \\
\hline Mean & & $96 \%$ \\
\hline
\end{tabular}

Hasil uji kepraktisan bagi guru berenisial NDA:

Tabel 9

Hasil uji kepraktisan bagi guru NDA

\begin{tabular}{ccc}
\hline No & Indikator & Persantase \\
\hline 1 & Aspek permainan pada & $93 \%$ \\
\hline
\end{tabular}


2253 Pengembangan Permainan Berburu Harta Karun Berbasis Karya Seni Lukis untuk Memfasilitasi Perkembangan Sosial Emosional Anak Usia Dini - Hafshania Nafisah, Edi Hendri Mulyana, Rosarina Giyartini

DOI: https://doi.org/10.31004/edukatif.v3i4.1165

\begin{tabular}{ccc}
\hline No & Indikator & Persantase \\
\hline \multicolumn{3}{c}{ permbelajaran } \\
\hline Mean & Aspek kelayakan permainan & $100 \%$ \\
\hline
\end{tabular}

Maka berdasarkan hasil uji kepraktisan produk bagi guru memperoleh 96\%. Selanjutnya hasil uji kepraktisan oleh anak yang diperoleh melalui penilaian dari observer.

Tabel 10

Hasil uji kepraktisan bagi anak

\begin{tabular}{ccc}
\hline No & Aspek Penilaian & Persantase \\
\hline 1 & $\begin{array}{c}\text { Memahami alat dan bahan } \\
\text { yang digunakan dalam proses } \\
\text { karya seni lukis }\end{array}$ & $95 \%$ \\
\hline 2 & $\begin{array}{c}\text { Permainan membangkitkan } \\
\text { aktivitas belajar anak }\end{array}$ & $95 \%$ \\
\hline 3 & $\begin{array}{c}\text { Permainan menarik minat } \\
\text { anak }\end{array}$ & $100 \%$ \\
\hline 4 & Permainan mudah digunakan & $91 \%$ \\
\hline 5 & $\begin{array}{c}\text { Desain permainan menarik } \\
\text { perhatian anak }\end{array}$ & $90 \%$ \\
\hline Mean & & $94,2 \%$ \\
\hline
\end{tabular}

Selanjutnya hasil uji efektifitas terhadap hasil permainan 6 anak pada kelompok B di TK Ibadurrahman, hasilnya 95,83\% dengan capaian perkembangan anak memperoleh nilai perkembangan sosial emosional adalah BSB (Berkembang Sangat Baik). Penelitian pengembangan ini menunjukkan bahwa produk permainan berburu harta karun berbasis karya seni lukis sangat efektik untuk memfasilitasi perkembangan sosial emosional AUD. Kriteria penilaian perkembangan anak diantaranya: a) Belum Berkembang (BB), b) Mulai Berkembang (MB), c) Berkembang Sesuai Harapan (BSH), d) Berkembang Sangat Baik. (Supena et al., 2018)

Tabel 11

Rekapitulasi Nilai Perkembangan Sosial Emosional Anak Usia Dini

\begin{tabular}{ccccccc}
\hline \multirow{2}{*}{ Aspek Perkembangan } & \multicolumn{7}{c}{ Jumlah Anak } \\
\cline { 2 - 7 } & A1 & A2 & A3 & A4 & A5 & A6 \\
\hline Percaya diri & BSB & BSB & BSB & BSB & BSB & BSB \\
\hline Manajemen diri & BSB & BSH & BSH & BSH & BSB & BSB \\
\hline Kesadaran sosial & BSB & BSB & BSB & BSB & BSB & BSH \\
\hline $\begin{array}{c}\text { Kemampuan membangun } \\
\text { hubungan }\end{array}$ & BSB & BSB & BSB & BSB & BSB & BSB \\
\hline Pengambilan keputusan & BSB & BSH & BSB & BSB & BSB & BSB \\
\hline Jumlah (\%) & 100 & 95 & 95 & 90 & 100 & 95 \\
\hline
\end{tabular}

Hasil keseluruhan $=\frac{100 \%+95 \%+95 \%+90 \%+100 \%+95}{6} \times 100 \%$

$$
=95,83 \% \text { (Berkembang Sangat Baik) }
$$

Sangat Efektif untuk memfasilitasi perkembangan sosial emosional anak usia dini

\section{Evaluasi dan Refleksi Pengembangan Permainan Berburu Harta Karun Berbasis Karya Seni Lukis untuk Memfasilitasi Perkembangan Sosial Emosional Anak Usia Dini}

Selanjutnya setelah memenuhi tahapan-tahapan pengembangan seperti analisis dasar kebutuhan, rancangan produk, dan kelayakan pengembangan permainan. Maka pada refleksi akhir produk menghasilkan 
2254 Pengembangan Permainan Berburu Harta Karun Berbasis Karya Seni Lukis untuk Memfasilitasi Perkembangan Sosial Emosional Anak Usia Dini - Hafshania Nafisah, Edi Hendri Mulyana, Rosarina Giyartini

DOI: https://doi.org/10.31004/edukatif.v3i4.1165

pengembangan permainan berburu harta karun berbasis karya seni lukis untuk memfasilitasi perkembangan sosial emosionl anak usia dini.

Evaluasi terkait kelebihan dan kekurangan dari pengembangan permainan berburu harta karun berbasis karya seni lukis, adalah 1) Kelebihan: permainan dirancang sesuai dengan Kompetensi Inti (KI) dan Kompetensi Dasar (KD) sesuai kurikulum 2013, permainan dirancang berdasarkan pembelajaran dan pengembangan pada anak, mudah digunakan, permainan berburu harta karun berbasis karya seni lukis menjadi konsep pembaharuan pembelajaran menjadi menyenangkan bagi anak. 2) Kekurangan: guru dalam menjalankan langkah-langkah permainannya harus mengerti, ekstra pengawasan dan perhatian pada setiap kelompok, durasi permainan cukup lama.

Ada kesesuaian dengan penelitian lain bahwa dengan permainan Fun Outbound Mencari Harta Karun dapat memfasilitasi pada arah pertumbahan dan perkembangan anak. (Safitri et al., 2020). Keterbatan dalam temuan ini terdapat pada: 1) waktu yang digunakan dalam kegiatan pembelajaran tidak bisa secara singkat karena penelitian memerlukan durasi yang cukup panjang. 2) Peserta didik belum terbiasa dengan permainan berburu harta karun dengan pembelajaran secara kelompok, sehingga guru lebih ekstra dalam mengkondisikan tempat agar penelitian berjalan lancar. Melalui penelitian ini diharapkan akan muncul pengetahuanpengetahuan baru dan terobosan terutama pada permainan yang dapat mengembangkan pertumbuhan dan perkembangan anak.

\section{KESIMPULAN}

Berdasarkan hasil pengembangan permainan ini dapat disimpulkan bahwa pengembangan permainan berburu harta karun berbasis karya seni lukis sesuai dengan dasar kebutuhan. Rancangan permainan ini hasil dari validasi ahli kurikulum \& pembelajaran AUD mendapatkan 89\%, ahli permainan mendapatkan 93\%, ahli materi pengembangan seni AUD mendapatkan 93\%, dan ahli perkembangan sosial emosional AUD 91\% dengan kategori semua ahli yaitu sangat layak. Kelayakan pengembangan permainan berdasarkan hasil uji kepraktisan guru senilai 96\%, hasil uji kepraktisan anak sebanyak 94,2\% dengan kategori sangat praktis. Selanjutnya hasil uji efektifitas pada perkembangan sosial emosional anak menunjukkan $95,93 \%$ kategorinya anak berkembangan sangat baik. Maka dari hal itu perkembangan permainan berburu harta karun berbasis karya seni lukis sangat efektif untuk memfasilitasi perkembangan sosial emosional anak usia dini.

\section{DAFTAR PUSTAKA}

Aprilia, Y. \& I. (2021). EDUKATIF: JURNAL ILMU PENDIDIKAN Pengembangan Permainan Ular Tangga Kimia Berbasis Android Sebagai Media Pembelajaran pada Materi Senyawa Hidrokarbon di Sekolah Menengah Atas. Jurnal Edukatif: Jurnal Pendidikan Anak Usia Dini, 3(4), 1220-1230.

Ardini, P., \& Lestariningrum, A. (2018). Ardini (Cetakan pe). CV. Adjie Media Nusantara.

CASEL. (2015). CASEL guide: effective social and emotional learning programs - middle and high school edition. Collaborative for Academic, Social and Emotional Learning, 1-45. http://secondaryguide.casel.org/

Ernawati, I. (2017). Uji Kelayakan Media Pembelajaran Interaktif Pada Mata Pelajaran Administrasi Server. Elinvo (Electronics, Informatics, and Vocational Education), 2(2), 204-210. https://doi.org/10.21831/elinvo.v2i2.17315

Fauziddin, M., \& Mufarizuddin, M. (2018). Useful of Clap Hand Games for Optimalize Cogtivite Aspects in Early Childhood Education. Jurnal Obsesi : Jurnal Pendidikan Anak Usia Dini, 2(2), 162. https://doi.org/10.31004/obsesi.v2i2.76

Gusmaniarti. (2018). Pengaruh Pembelajaran Sentra Seni dan Kreatifitas Kelompok A di Ra Roudlotul Hamdi Rembang Pasuruan Gusmaniarti Dosen Universitas Muhammadiyah Surabaya Email : 
2255 Pengembangan Permainan Berburu Harta Karun Berbasis Karya Seni Lukis untuk Memfasilitasi Perkembangan Sosial Emosional Anak Usia Dini - Hafshania Nafisah, Edi Hendri Mulyana, Rosarina Giyartini

DOI: https://doi.org/10.31004/edukatif.v3i4.1165

gusmaniarti01@gmail.com PENDAHULUAN Usia dini merupakan periode emas ( the golden age ) bagi pe. PEDAGOGI: Jurnal Anak Usia Dini Dan Pendidikan Anak Usia Dini, 4(2), 56-61.

Helaluddin, \& Alamsyah. (2019). Kajian Konseptual Tentang Social-Emotional. Al-Ishlah: Jurnal Pendidikan, 11(1), 1-16.

Lidinillah, D. A. M. (2012). Educational Design Research : a Theoretical Framework for Action. Jurnal UPI, 1, Bandung: UPI Kampus Tasikmalaya.

Menteri Pendidikan dan Kebudayaan Republik Indonesia. (2014). Standar Nasional Pendidikan Anak Usia Dini. Peraturan Menteri Pendidikan Dan Kebudayaan Republik Indonesia, 13.

Mukhlis, A., \& Mbelo Handayani, F. (2019). Analisis perkembangan sosial emosional anak usia dini pada permainan tradisional. Perkembangan Dan Pendidikan Anak Usia Dini, Vol. 1 No.(Oktober), 11-28.

Pamadhi, H. \& S. (2018). Seni Keterampilan Anak (kedua pulu). Universitas Terbuka.

Safitri, W., Sumardi, S., \& Muslihin, H. Y. (2020). Pengembangan Bahan Ajar Permainan Fun Outbound Mencari Harta Karun. Jurnal Paud Agapedia, 4(1), 96-106. https://doi.org/10.17509/jpa.v4i1.27201

Sugiyono. (2019). Metode Penelitian Kuantitatif, Kualitatif, dan R\&D (26th ed.). CV Alfabeta.

Supena, A., Jaya, I., \& Paramita, D. (2018). Penilaian dan Laporan Perkembangan. Direktorat Pendidikan Anak Usia Dini, 021, 1-25.

Veronika, A., \& Puspitasari, E. (2018). The Effectiveness Of Treasurehunt Game On The Logical Mathematical Intelligence Of Children Ages 5-6 Years In TK Shandy Putra Telkom Pekanbaru Pada Anak Usia 5-6 Tahun Di TK Shandy. Jurnal Online Mahasiswa Fakultas Kegurusan Dan Ilmu Pendidikan, 5(1), 1-15.

Wijaya Kuswanto, C., \& Dinda Pratiwi, D. (2020). Pengembangan Bahan Ajar Pendidikan Jasmani untuk Anak Usia Dini Berbasis Tematik. Al-Athfal: Jurnal Pendidikan Anak, 6(1), 55-68. https://doi.org/10.14421/al-athfal.2020.61-05

Wina, R. P., Iriyanto, T., \& Aisyah, E. N. (2019). Pengembangan Permainan Harta Karun Si Bola-Bola dalam Pembelajaran Sosial Emosional Anak Usia 5-6 Tahun di Taman Kanak-Kanak. Jurnal Pendidikan Anak, 8(2), 126-131. https://doi.org/10.21831/jpa.v8i2.29095

Wiratno, T. A. (2018). Seni Lukis Konsep Dan Metode. CV. Zifatama Jawara. https://doi.org/10.31227/osf.io/2z57p

Wiwik Pratiwi. (2017). Konsep Bermain Pada Anak Usia Dini. Manajemen Pendidikan Islam , 5, 106-117.

Yuninigsih, C. R. (2019). Pembelajaran Seni Rupa Di Pendidikan Anak Usia Dini. Jurnal Edukasi Sebelas April, 3(1), 1-7. 